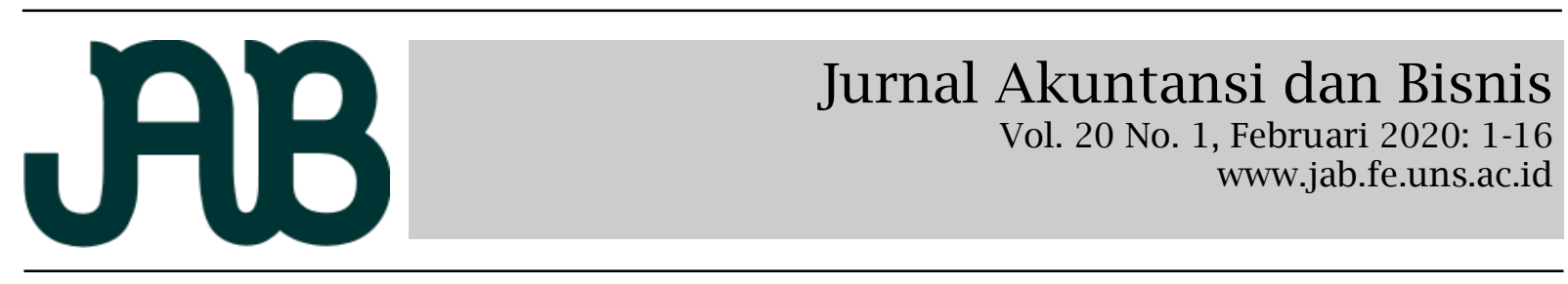

\title{
PERSISTENSI LABA ANTAR LEVEL KOMPETISI INDUSTRI: STUDI EMPIRIS PADA PERUSAHAAN AMERIKA SERIKAT
}

\author{
NURUL AISYAH RACHMAWATI ${ }^{1}$ (nurulaisyah@universitas-trilogi.ac.id) \\ SIDHARTA UTAMA ${ }^{2}$ \\ SYLVIA VERONICA NALURITA PURNAMA SIREGAR ${ }^{3}$
}

${ }^{1}$ Program Studi Akuntansi, Fakultas Ekonomi dan Bisnis, Universitas Trilogi Jakarta, Indonesia

${ }^{2,3}$ Program Studi Akuntansi, Fakultas Ekonomi dan Bisnis, Universitas Indonesia

\begin{abstract}
A B S T R A C T
The purpose of this study is to analyze the effect of industry competition level on earnings persistence components. This study used panel data of listed companies that have common shares listed on one of the three major US stock exchanges (NYSE, AMEX, or NASDAQ) and a GICS code during the period 2012-2014. This study hypothesized that industry-wide earnings in the low-competition industries are more persistent than industry-wide earnings in the high-competition industries. The results provide evidence which is consistent with the hypothesis. Finally, I hypothesized and found that industry-wide cashflows in the low-competition industries are the most persistent component of earnings, while firm-specific accruals in the high-competition industries is the least persistent.

Keywords: industry-wide earnings, firm-specific earnings, earnings persistence, cash flows persistence, accruals persistence, level of industry competition

Penelitian ini bertujuan untuk menganalisis pengaruh level kompetisi industri terhadap komponen persistensi laba. Penelitian ini menggunakan data panel perusahaan yang terdaftar di salah satu dari tiga bursa efek Amerika serikat yang utama (NYSE, AMEX, atau NASDAQ) selama periode 2012-2014. Klasifikasi industri didasarkan pada GICS code. Penelitian ini mengembangkan hipotesis bahwa komponen industry-wide atas laba pada low-competition industries lebih persisten dibandingkan komponen industry-wide atas laba pada high-competition industries. Studi ini menunjukkan hasil yang konsisten dengan hipotesis. Terakhir, penelitian ini mengembangkan hipotesis dan menemukan bahwa komponen industry-wide atas arus kas pada low-competition industries paling persisten dibandingkan dengan komponen yang lainnya.

Kata kunci: komponen industry-wide atas laba, komponen firm-specific atas laba, persistensi laba, persistensi arus kas, persistensi akrual, level kompetisi industri
\end{abstract}

\section{PENDAHULUAN}

Penelitian ini bertujuan untuk menginvestigasi apakah persistensi laba, arus kas, dan akrual dipengaruhi oleh level kompetisi di suatu industri. Berdasarkan teori ekonomi dalam Hui, Nelson \& Yeung (2016), kinerja perusahaan yang dipengaruhi oleh industri secara fundamental (seperti selera konsumen, teknologi produksi, dan regulasi) relatif bersifat jangka panjang (Dichev, Graham, Harvey \& Rajgopal, 2013; Wahlen, Baginski \& Bradshaw, 2015). Dengan demikian, kondisi suatu industri memiliki peran penting dalam menentukan kinerja perusahaan. Informasi kinerja perusahaan, baik yang berupa laba/rugi maupun komponen-komponen dari laba/rugi, merupakan salah satu informasi yang sering digunakan oleh pihak-pihak yang berkepentingan (stakeholders) untuk membantu proses pengambilan keputusan. Dengan demikian, kualitas laba perusahaan selalu menjadi perhatian stakeholders.

Analis dan investor dapat menilai kesuksesan kinerja perusahaan dari persistensi laba (Baginski, Lorek, Willinger \& Branson, 1999). Laba dapat dikatakan berkualitas jika mencerminkan laba yang berkelanjutan (sustainable earnings) di masa depan (Atashband, Moienadin \& Tabata- 
baenasab, 2014). Laba yang berkelanjutan tersebut dapat diproksikan dengan persistensi laba (Dechow, Ge \& Schrand, 2010). Pasalnya, persistensi laba mengandung unsur predictive value sehingga dapat digunakan untuk mengevaluasi kejadiankejadian di masa lalu, sekarang, dan masa depan oleh stakeholders (Rachmawati dan Martani, 2014; Rachmawati, 2016; Merrysa dan Rachmawati, 2017). Namun, beberapa studi terdahulu masih fokus pada persistensi atas laba yang dilaporkan oleh perusahaan, tanpa mempertimbangkan adanya dampak industry-wide sebagai komponen atas laba yang dilaporkan terhadap persisensi laba (seperti Sloan, 1996; Rachmawati dan Martani, 2014; Meini dan Siregar, 2014; Rachmawati, 2016; Merrysa dan Rachmawati, 2017; Fatma \& Hidayat, 2019).

Dalam studinya, Hui et al., (2016) menyatakan bahwa laba/rugi perusahaan terdiri dari dua komponen, yaitu komponen laba/rugi yang mencerminkan kondisi suatu industri (industri-wide) dan komponen laba/rugi yang mencerminkan kondisi suatu perusahaan (firm-specific). Oleh karena industri memberikan dampak yang fundamental terhadap kinerja perusahaan, Hui et al. (2016) memrediksi dan menemukan bahwa komponen industry-wide atas laba lebih persisten dibandingkan dengan komponen firm-specific.

Atas dasar teori ekonomi yang menyatakan bahwa suatu industri bersifat homogeneity dan stationarity, Hui et al., (2016) juga memrediksi bahwa perusahaan dalam homogeneous industries (misalnya memiliki produk sejenis, faktor yang memengaruhi transaksi perusahaan serupa, dan teknologi produksi yang digunakan sama) akan menghadapi tantangan ekonomis yang relatif sama. Siklus bisnis perusahaan yang ada dalam homogeneous industries juga memiliki perbedaan dengan heterogeneous industries (Meini, Safuan, Dewo \& Diyanti, 2018). Dengan demikian, komponen industry-wide atas laba perusahaan dalam homogeneous industries lebih persisten dibandingkan dengan perusahaan yang berada dalam heterogeneous industries. Sesuai dengan dugaan, Hui et al. (2016) menemukan bahwa laba yang berasal dari komponen industry-wide lebih persisten dalam homogeneous industries dibandingkan dengan dalam heterogeneous industries. Sebaliknya, persistensi komponen firm-specific atas laba relatif tidak berubah, baik dalam homogeneous industries maupun heterogeneous industries.

Hui et al., (2016) memrediksi dan menemukan bahwa komponen laba juga lebih persisten pada industri yang stabil dibandingkan dengan pada industri yang terganggu dengan business shocks. Dampak dari business shocks tersebut akan lebih kecil pada komponen industry-wide atas laba dibandingkan dengan komponen firmspecific atas laba (Guay, Taylor \& Xiao, 2014). Pasalnya, komponen industry-wide atas laba secara umum relatif lebih tidak banyak mengalami perubahan (Ecker, Francis, Olsson \& Schipper, 2013).

Penelitian ini mengembangkan studi Hui et al., (2016) dalam dua hal. Pertama, penelitian ini menguji apakah persistensi industry-wide sebagai komponen atas laba dipengaruhi oleh level kompetisi industri. Beberapa literatur menunjukkan bahwa industri yang kompetitif dapat memengaruhi perilaku manajerial (seperti Mueller, 1977; Baginski et al., 1999) serta strategi bisnis dan ketidakpastian lingkungan (seperti Arieftiara, Utama dan Wardhani, 2017; Arieftiara, Utama, Wardhani \& Rahayu, 2019). Baginski et al., (1999) menyatakan bahwa perusahaan yang berada pada industri dengan barriers-to-entry yang tinggi (product differentiation dan product innovation), memiliki market share yang relatif stabil sehingga cenderung memiliki laba yang lebih persisten. Menurut Hui et al., (2016), komponen laba juga lebih persisten pada industri yang stabil dibandingkan dengan pada industri yang terganggu dengan business shocks. Berdasarkan hasil penelitian terdahulu tersebut, penulis menduga bahwa komponen industry-wide atas laba pada low-competition industries lebih persisten dibandingkan komponen industry-wide atas laba pada highcompetition industries.

Kedua, oleh karena persistensi laba juga dapat ditentukan oleh komponen akrual dan arus kas yang terkandung dalam laba saat ini (Sloan, 1996; Green, Hand \& Soliman, 2011), penelitan ini juga men- 
guji apakah terdapat perbedaan persistensi industry-wide dan firm-specific sebagai komponen atas arus kas dan akrual pada level kompetisi industri yang beragam. Sloan (1996) membuktikan bahwa komponen akrual dari laba kurang persisten terhadap laba di masa depan dibandingkan dengan komponen arus kas dari laba. Hui et al., (2016) menunjukkan bahwa industrywide atas arus kas merupakan komponen laba yang paling persisten sementara firmspecific atas akrual merupakan komponen laba yang paling kurang persisten. Atas dasar kedua hasil studi tersebut, penelitian ini menduga bahwa komponen industrywide atas arus kas pada low-competition industries merupakan komponen yang paling persisten jika dibandingkan dengan komponen lainnya. Selain itu, penelitian ini juga menduga bahwa komponen firmspecific atas akrual pada high-competition industries merupakan komponen yang paling kurang persisten jika dibandingkan dengan komponen lainnya.

Penelitian ini berkontribusi dalam menambah literatur terkait persistensi laba. Penelitian ini menunjukkan bahwa terdapat perbedaan persistensi komponen industry-wide dan firm-specific yang terkandung dalam laba, arus kas, dan akrual antara high-competition industries dan lowcompetition industries. Dalam penelitian Hui et al., (2016) tidak mengakomodir dampak level kompetisi industri terhadap persistensi laba, hanya menguji dampak industry homogeneity dan business shocks. Pengujian ini diharapkan dapat memberikan informasi bagi investor, bahwa perusahaan dengan level kompetisi industri yang berbeda memiliki persistensi yang berbeda pula. Dengan demikian, ketika melakukan penilaian terhadap suatu perusahaan, investor sebaiknya tidak hanya terfokus pada laba yang dilaporkan perusahaan saja, melainkan juga mempertimbangkan faktorfaktor lain, seperti level kompetisi industri perusahaan.

Selanjutnya penelitian ini akan menyajikan tinjauan pustaka dan beberapa riset terdahulu sebagai dasar pengembangan hipotesis. Riset ini juga menyajikan metode penelitian beserta hasil penelitiannya. Terakhir, studi ini membuat simpulan, keterbatasan penelitian, dan pengembangan untuk riset selanjutnya di masa yang akan datang.

\section{TINJAUAN PUSTAKA DAN PENGEM- BANGAN HIPOTESIS \\ Level Kompetisi Indusri terhadap Persis- tensi Laba}

Teori ekonomi dalam Hui et al., (2016) menjelaskan bahwa kinerja perusahaan terkait erat dengan industri secara fundamental (seperti selera konsumen, teknologi produksi, dan regulasi). Faktor industri yang mendasar ini memberikan dampak yang relatif bersifat jangka panjang terhadap kinerja perusahaan, yang akan tercermin dalam laba perusahaan (Hui et al., 2016). Dengan membedakan laba perusahaan menjadi komponen industry-wide dan firm-specific. Hui et al., (2016) menduga dan berhasil menemukan bahwa komponen industry-wide atas laba lebih persisten dibandingkan dengan komponen firm-specific. Dengan demikian, Hui et al., (2016) beranggapan bahwa laba akuntansi perusahaan merupakan sebuah ukuran profit ekonomis yang noise karena tidak mencerminkan kondisi laba perusahaan saja, melainkan juga laba yang dipengaruhi oleh faktor industri.

Beberapa literatur menunjukkan bahwa industri yang kompetitif dapat memengaruhi perilaku manajerial dalam menyajikan laporan keuangan. Dengan demikian, hal ini juga akan berdampak pada kualitas laba suatu perusahaan. Berdasarkan Mueller (1977) semakin tinggi barriers-to-entry, semakin menurunkan level kompetisi karena terdapat batasan bagi perusahaan baru untuk masuk ke dalam industri tersebut. Penurunan kompetisi tersebut menyebabkan market share menjadi relatif stabil (Li, 2010; Healy, Serafeim, Srinivasan \& Yu, 2014; Marlianti \& Devie, 2017). Perusahaan yang berada dalam industri tersebut dapat memiliki pertumbuhan laba yang berkelanjutan (sustainable).

Sesuai dengan temuan Baginski et al., (1999), perusahaan yang berada pada industri dengan barriers-to-entry yang tinggi (product differentiation dan product innovation), memiliki market share yang relatif 
stabil sehingga cenderung memiliki laba yang lebih persisten. Siklus bisnis perusahaan dalam homogeneous industries juga memiliki perbedaan dibandingkan dengan heterogeneous industries (Meini et al., 2017). Menurut Hui et al., (2016), komponen laba juga lebih persisten pada industri yang stabil dibandingkan dengan pada industri yang terganggu dengan business shocks. Berdasarkan hasil penelitian tersebut, dikembangkan hipotesis berikut ini:

H1: Komponen industry-wide atas laba pada low-competition industries lebih persisten dibandingkan komponen industry-wide atas laba pada highcompetition industries.

\section{Level Kompetisi Industri terhadap Persis- tensi Arus Kas dan Akrual}

Sloan (1996) membuktikan bahwa komponen akrual dari laba kurang persisten terhadap laba di masa depan dibandingkan dengan komponen arus kas dari laba. Pasalnya, akrual mengandung unsur estimasi dan diskresi dari manajemen sehingga dapat menyebabkan kurang perisisten. Menurut Hui et al., (2016), persistensi komponen industry-wide atas laba yang lebih besar dibandingkan dengan komponen firm-specific atas laba seharusnya juga tercermin pada persistensi komponen arus kas dan akrual yang terkandung dalam laba saat ini. Hui et al., (2016) menunjukkan bahwa industry-wide atas arus kas merupakan komponen laba yang paling persisten sementara firm-specific atas akrual merupakan komponen laba yang paling kurang persisten.

Menurut Dechow \& Dichev (2002), perusahaan yang melaporkan laba negatif akan memiliki kualitas laba yang lebih rendah dibandingkan dengan perusahaan yang melaporkan laba positif. Pada konteks penelitian ini, perusahaan yang berada pada komponen industry-wide atas laba yang negatif akan cenderung memiliki persistensi yang lebih rendah dibandingkan dengan perusahaan yang berada pada komponen industry-wide atas laba yang positif.

Selaras dengan penelitian Hui et al. , (2016), Sloan (1996), dan Dechow \& Dichev (2002), penelitian ini menguji apakah komponen industry-wide atas arus kas pada low -competition industries yang memiliki industry-wide atas laba positif merupakan komponen yang paling persisten jika dibandingkan dengan komponen lainnya. Begitu pula sebaliknya, penelitian ini juga menguji apakah komponen firm-specific atas akrual pada high-competition industries yang memiliki industry-wide atas laba negatif merupakan komponen yang paling kurang persisten jika dibandingkan dengan komponen lainnya.

H2a: Komponen industry-wide atas arus kas perusahaan yang berada pada industri dengan level kompetisi yang rendah dan memiliki laba industri yang positif, merupakan komponen yang paling persisten jika dibandingkan dengan komponen lainnya.

H2b: Komponen firm-specific atas akrual pada perusahaan yang berada pada industri dengan level kompetisi yang tinggi dan memiliki laba industri yang negatif, merupakan komponen yang paling kurang persisten jika dibandingkan dengan komponen lainnya.

\section{METODE PENELITIAN}

Sesuai dengan Hui et al., (2016), penelitian ini menggunakan analisis data panel perusahaan yang listed di salah satu dari tiga bursa saham utama di US (NYSE, AMEX atau NASDAQ). Perusahaan yang dual listing tidak dimasukkan dalam sampel karena perusahaan tersebut menghadapi regulasi yang lebih ketat, yaitu lebih dari satu regulasi pasar modal harus dipatuhi sehingga dapat memengaruhi pelaporan keuangan perusahaan. Penelitian ini menggunakan Thomson Reuters Eikon database pada periode 2012-2014. Salah satu variabel dalam penelitian ini menggunakan tahun $\mathrm{t}+1$. Dengan demikian, untuk periode penelitian tahun 2014, variabel ini menggunakan data tahun 2015. Penelitian ini tidak menggunakan tahun 2016 karena pada tahun tersebut pertumbuhan ekonomi US sangat lambat yang diduga akan memengaruhi tingkat kompetisi industrinya. Hal ini dapat memberikan hasil penelitian yang bias.

Penelitian ini memilih konteks negara US karena sebagian besar perusahaan di US 
terdaftar pada bursa efek. Dengan demikian informasi mengenai industri yang digunakan dalam penelitian ini lebih mencerminkan kondisi industri yang sebenarnya. Pengklasifikasian industri dilakukan berdasarkan digit ke-8 GICS (Global Industry Classification Standard) code. Penelitian ini mengeluarkan perusahaan-perusahaan yang berada di industri keuangan (dua-digit GICS code) karena sifatnya yang unik dibandingkan dengan industri lain. Perusahaan sampel dalam penelitian ini harus memiliki seluruh komponen yang diperlukan sebagai variabel regresi penelitian. Jumlah sampel akhir dalam penelitian ini adalah 5.863 perusahaan atau 17.589 perusahaan-tahun seperti yang dapat dilihat pada Tabel 1.

\section{Model Penelitian}

Berikut ini adalah model dasar persistensi laba yang dikembangkan dari penelitian Hui et al., (2016):

$$
\begin{aligned}
\text { Earnings }_{\mathrm{it}+1}= & \alpha_{0}+\alpha_{1} \operatorname{IndE}_{\mathrm{it}}+\alpha_{2} \text { FirmE }_{\mathrm{it}}+\alpha_{3} \mathrm{Neg}_{\mathrm{it}}+ \\
& \alpha_{4} \operatorname{IndE}_{\mathrm{it}}{ }^{*} \mathrm{Neg}_{\mathrm{it}}+\alpha_{5} \text { FirmE }_{\mathrm{it}} * \mathrm{Neg}_{\mathrm{it}} \\
& +\varepsilon_{1 \mathrm{it}+1 .} \ldots \ldots \ldots \ldots \ldots \ldots \ldots \ldots \ldots \ldots \ldots \ldots \ldots \ldots \ldots \ldots \ldots \ldots \ldots \ldots
\end{aligned}
$$

Earnings $_{i t+1}$ adalah laba sebelum pajak untuk perusahaan i pada tahun $\mathrm{t}+1$. IndE $E_{i t}$ adalah komponen industry-wide atas laba untuk perusahaan i pada tahun t. FirmE $E_{i t}$ adalah komponen firm-specific atas laba untuk perusahaan i pada tahun t. $\mathrm{Neg}_{i t}$ adalah dummy variable, di mana "1" jika IndE $E_{i t}$ bernilai negatif dan "0" jika lainnya. Untuk mengontrol ukuran perusahaan, semua variabel di atas (kecuali $\mathrm{Neg}_{i t}$ ) diskalakan dengan rata-rata total aset pada

Tabel 1.

Deskripsi Sampel: Komposisi Industri

\begin{tabular}{lll}
\hline $\begin{array}{c}\text { Dua-digit } \\
\text { GICS code }\end{array}$ & Sektor Industri & $\begin{array}{c}\text { Jml. } \\
\text { Observasi }\end{array}$ \\
\hline 10 & Energy & 1.686 \\
15 & Materials & 1.659 \\
20 & Industrials & 3.432 \\
25 & Cons. Discretion- & 3.381 \\
30 & ary & 1.275 \\
35 & Cons. Staples & 1.980 \\
45 & Health Care & 3.057 \\
50 & Information & 453 \\
55 & Tech. & 666 \\
& Telecom. Services & 17.589 \\
\hline
\end{tabular}

tahun $\mathrm{t}-1$ dan tahun $\mathrm{t}$.

Untuk menguji $\mathrm{Hl}$, penelitian ini mengembangkan persamaan (1) dengan memasukkan variabel CompInd ${ }_{i t}$. Dengan demikian, penelitian ini menggunakan persamaan estimasi berikut:

$$
\begin{aligned}
& \text { Earnings }_{\mathrm{it}+1}=\quad \alpha_{0}+\alpha_{1} \operatorname{IndE}_{\mathrm{it}}+\alpha_{2} \text { FirmE }_{\mathrm{it}}+\alpha_{3} \mathrm{Neg}_{\mathrm{it}} \\
& +\alpha_{4} \text { CompInd }_{\text {it }}+\alpha_{5} \text { IndE }_{\text {it }}{ }^{*} \mathrm{Neg}_{\text {it }} \\
& +\alpha_{6} \text { FirmE }_{\mathrm{it}}{ }^{*} \mathrm{Neg}_{\mathrm{it}}+\alpha_{7} \operatorname{IndE}_{\mathrm{it}}{ }^{*} \\
& \text { CompInd }_{\text {it }}+\alpha_{8} \text { FirmE }_{\text {it }}^{*} \text { Com- } \\
& \text { pInd }_{\text {it }}+\alpha_{9} \text { IndE }_{\text {it }} * \mathrm{Neg}_{\mathrm{it}}{ }^{*} \text { Com- } \\
& \text { pInd }_{i t}+\alpha_{10} \text { FirmE }_{i t} * \mathrm{Neg}_{\mathrm{it}}{ }^{*} \\
& \text { CompInd }_{\mathrm{it}}+\varepsilon_{\mathrm{it}+1}, \ldots \ldots \ldots \ldots \text { (2) }
\end{aligned}
$$

Dimana CompInd adalah dummy variable, di mana "1" untuk lowcompetition industries jika nilai $C O V_{t}$ di atas median $C O V_{\text {t }}$ sampel industri, dan "0" untuk lainnya (high-competition industries).

Selaras dengan H1, penulis memrediksi koefisien variabel interaksi IndE${ }_{i t}^{*}$ CompInd $_{i t}\left(\alpha_{7}\right)$ akan bernilai positif. Dengan demikian, $\alpha_{1}+\alpha_{7}$ menjadi lebih besar dibandingkan dengan $\alpha_{1}$. Artinya, komponen industry-wide atas laba pada lowcompetition industries lebih persisten dibandingkan komponen industry-wide atas laba pada high-competition industries.

Untuk meminimalkan mispriced securities yang disebabkan oleh investor yang terlalu fokus pada reported earnings saat membuat keputusan, perlu dilakukan analisis akrual dan arus kas (Sloan, 1996). Dengan mengembangkan persamaan (2), penelitian ini menggunakan persamaan estimasi berikut:

Dimana IndCFit adalah Rata-rata arus kas operasi (CFit) untuk semua perusahaan

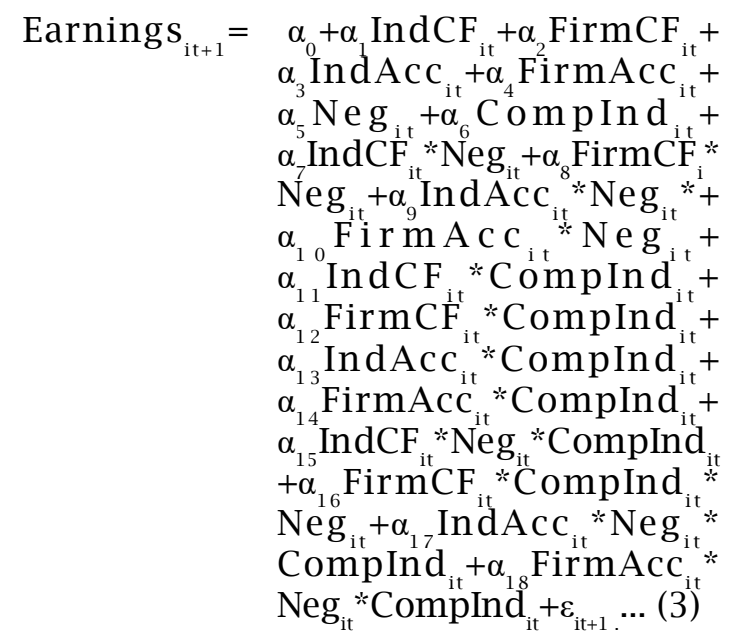


dalam industri yang sama pada periode $t$. IndAccit merupakan selisih antara IndEit \& IndCFit. FirmCFit adalah selisih antara CFit dan IndCFit. FirmAccit merupakan selisih antara FirmEit \& FirmCFit. Untuk mengontrol ukuran perusahaan, semua variabel di atas diskalakan dengan rata-rata total aset pada tahun $\mathrm{t}-1$ dan tahun $\mathrm{t}$.

Sesuai dengan $\mathrm{H} 2 \mathrm{a}$, penulis menduga koefisien IndCFit*CompIndit $(\alpha 11)$ bernilai positif dan komponen industry-wide atas arus kas pada low-competition industries merupakan komponen yang paling persisten jika dibandingkan dengan komponen lainnya. Dengan demikian, $\alpha 1+\alpha 11$ akan bernilai paling besar dibandingkan dengan $\alpha 1$; $\alpha 2 ; \quad \alpha 3 ; \quad \alpha 4 ; \quad \alpha 1+\alpha 7 ; \quad \alpha 2+\alpha 8 ; \quad \alpha 3+\alpha 9 ; \quad \alpha 4+\alpha 10 ;$ $\alpha 2+\alpha 12 ; \quad \alpha 3+\alpha 13 ; \quad \alpha 4+\alpha 14 ; \quad \alpha 1+\alpha 7+\alpha 11+\alpha 15 ;$ $\alpha 2+\alpha 8+\alpha 12+\alpha 16 ; \quad \alpha 3+\alpha 9+\alpha 13+\alpha 17 ; \quad$ d a n $\alpha 4+\alpha 10+\alpha 14+\alpha 18$.

Sesuai dengan $\mathrm{H} 2 \mathrm{~b}$, penulis menduga komponen firm-specific atas akrual pada high-competition industries dengan IndEit negatif merupakan komponen yang paling kurang persisten jika dibandingkan dengan komponen lainnya. Hal ini mengindikasikan bahwa hubungan antara komponen industry-wide atas arus kas terhadap laba masa depan paling persisten dibandingkan dengan komponen lainnya. Selain itu, hubungan antara firm-specific atas akrual terhadap laba masa depan paling tidak persisten dibandingkan dengan komponen lainnya. Jadi, $\alpha 4+\alpha 10$ akan bernilai paling kecil dibandingkan dengan $\alpha 1 ; \alpha 2 ; \alpha 3 ; \alpha 4$; $\alpha 1+\alpha 7 ; \alpha 2+\alpha 8 ; \alpha 3+\alpha 9 ; \alpha 1+\alpha 11 ; \alpha 2+\alpha 12 ; \alpha 3+\alpha 13$; $\alpha 4+\alpha 14 ; \quad \alpha 1+\alpha 7+\alpha 11+\alpha 15 ; \quad \alpha 2+\alpha 8+\alpha 12+\alpha 16 ;$ $\alpha 3+\alpha 9+\alpha 13+\alpha 17$; dan $\alpha 4+\alpha 10+\alpha 14+\alpha 18$.

\section{Definisi Operasional dan Pengukuran Variabel \\ Pengukuran Komponen Industry-Wide dan Firm-Specific atas Laba}

Penelitian ini membedakan laba menjadi dua komponen, yaitu industry-wide dan firm-specific. Sesuai dengan Hui et al., (2016), laba industry-wide merepresentasikan komponen laba untuk semua perusahaan dalam industri yang sama. Sementara itu, laba firm-specific merupakan selisih antara laba perusahaan dan rata-rata laba dalam suatu industri. Secara spesifik, Earningsi,j,t merupakan laba dari perusahaan i dalam industri $\mathrm{j}$ untuk tahun $\mathrm{t}$, yang diukur dengan laba sebelum pajak yang diskalakan dengan rata-rata total aset (Sloan 1996). Dengan mengasumsikan N perusahaan berada dalam industri $\mathrm{j}$, maka laba industry-wide atas industri $\mathrm{j}$ untuk tahun $\mathrm{t}$ $\left(\operatorname{IndE}_{j, 1}\right)$ didefinisikan sebagai berikut:

$$
\operatorname{IndE}_{\mathrm{jt}}=1 / \mathrm{N}^{*} \sum_{\mathrm{N}, \mathrm{i}=1} \text { Earnings }_{\mathrm{ijt}}
$$

Dengan demikian, laba firm-specific perusahaan i dalam industri j untuk tahun $\mathrm{t}\left(\right.$ FirmE $\left._{i, j, l}\right)$ didefinisikan sebagai berikut:

$$
\text { FirmE }_{\mathrm{ijt}}=\text { Earnings }_{\mathrm{ijt}}-\operatorname{IndE}_{\mathrm{jt}} .
$$

\section{Pengukuran Komponen Industry-Wide dan Firm-Specific atas Arus Kas dan Akrual}

Dengan menggunakan pendekatan yang sama dengan Hui et al., (2016), penulis membedakan laba industry-wide (IndEt) menjadi arus kas operasi industry-wide (IndCFt) dan akrual industry-wide (IndAcct):

$$
\operatorname{IndE}_{\mathrm{t}}=\operatorname{IndCF}_{\mathrm{t}}-\text { IndACc }_{\mathrm{t}}
$$

IndCFt adalah rata-rata arus kas operasi yang diskalakan dengan rata-rata total aset $(C F t)$ untuk semua perusahaan dalam industri yang sama, dan IndAcct adalah selisih antara IndEt dan IndCFt.

Penulis juga membedakan laba firmspecific (FirmEt) menjadi arus kas operasi firm-specific (FirmCFt) dan akrual firmspecific (FirmAcct):

$$
\text { FirmE }_{\mathrm{t}}=\text { FirmCF }_{\mathrm{t}}-\text { FirmAcc }_{\mathrm{t}} \ldots \ldots \ldots \ldots \ldots . .(7)
$$

Dimana FirmCFt merupakan selisih CFt dan IndCFt. FirmAcct adalah selisih FirmEt dan FirmCFt.

\section{Pengukuran Level Kompetisi Industri}

Penelitian ini menggunakan pendekatan size inequality dalam pengukuran level kompetisi industri (Du \& Chen 2010). Ukuran ini lebih baik dibandingkan dengan ukuran yang menggunakan pendekatan market consentration (misalnya HerfindahlHirschman index) karena mempertimbangkan besaran distribusi perusahaan di dalam industri. Dalam Du \& Chen (2010) dijelaskan bahwa salah satu ukuran kompetisi berdasarkan pendekatan ini adalah coefficient of variation (COV), yang dapat 
dihitung dengan persamaan berikut:

Dimana $x_{i}$ adalah sales perusahaan $\mathrm{i}$ dan $\mathrm{n}$ adalah jumlah perusahaan dalam industri. Semakin besar nilai $C O V_{t}$ menunjukkan semakin besarnya inequality ukuran perusahaan dalam suatu industri. Menurut Du \& Chen (2010), semakin tinggi inequality ukuran perusahaan dalam industri, maka level kompetisi industrinya cenderung rendah. Berdasarkan hasil perhitungan persamaan (8), kemudian penelitian ini mendefinisikan dummy variable CompInd ${ }_{i t}$ sebagai proksi dari level kompetisi industri, di mana "1" untuk low-competition industries jika nilai $C O V_{t}$ di atas median $C O V_{t}$ sampel industri, dan " 0 " untuk lainnya (high-competition industries).

\section{ANALISIS DAN PEMBAHASAN}

$$
\operatorname{COV}_{\mathrm{t}}=\sqrt{\frac{1}{n} \sum_{i=1}^{n}\left(x_{i t}-\bar{x}_{t}\right) / \bar{x}_{t}} \ldots
$$

Satu hal yang penting untuk diperhatikan dari hasil statistik deskriptif sebagaimana tersaji dalam Tabel 1 adalah variabel $\mathrm{Neg}_{i t^{*}}$ Berdasarkan Tabel 2 Panel A diketahui bahwa $25.6 \%$ perusahaan dalam periode penelitian berada dalam kondisi laba industri $\left(I n d E_{i i}\right)$ yang negatif. Hal ini tentu memberikan dampak tersendiri terhadap perilaku perusahaan. Menurut Dechow \& Dichev (2002), perusahaan yang melaporkan laba negatif akan memiliki kualitas laba yang lebih rendah dibandingkan dengan perusahaan yang melaporkan laba positif. Pada konteks penelitian ini, perusahaan yang berada pada komponen industry-wide atas laba yang negatif akan cenderung memiliki persistensi yang lebih rendah dibandingkan dengan perusahaan yang berada pada komponen industry-wide atas laba yang positif.

Namun demikian, jika ditinjau dari variabel $I n d E_{i t,}$ diketahui bahwa rata-rata komponen industry-wide atas laba setelah diskalakan dengan rata-rata total aset sebesar 0.013. Hal ini mengindikasikan bahwa rata-rata industri dalam periode penelitian berada dalam kondisi laba yang positif. Besarnya variabel $I n d E_{i t}$ ini berdampak pada besaran FirmE it Dalam Tabel 2 Panel A diketahui bahwa rata-rata komponen firmspecific atas laba setelah diskalakan dengan rata-rata total aset sebesar -0.001 . Namun

Tabel 2.

Statistik Deskriptif dan Correlation Matrix

Panel A: Statistik Deskriptif

\begin{tabular}{|c|c|c|c|c|c|c|c|c|c|}
\hline & $\underline{E}_{i t+1}$ & $\underline{\text { IndE }}_{\mathrm{it}}$ & $\underline{\text { Firm }}_{\text {it }}$ & $\underline{\operatorname{IndC}}_{\mathrm{it}}$ & $\underline{\text { FirmCF }}_{\text {it }}$ & $\underline{\text { IndAcc }}_{\text {it }}$ & $\underline{\text { FirmAcc }}_{\text {it }}$ & $\frac{\text { Com- }}{\text { pInd }}$ & $\underline{\mathrm{Neg}}_{\text {is }}$ \\
\hline Mean & 0.019 & 0.013 & -0.001 & 0.060 & 0.000 & -0.047 & -0.001 & 0.653 & 0.256 \\
\hline Median & 0.045 & 0.024 & 0.014 & 0.070 & 0.008 & -0.039 & 0.007 & 1.000 & 0.000 \\
\hline Maks. & 0.994 & 0.145 & 1.055 & 0.161 & 0.950 & 0.041 & 1.570 & 1.000 & 1.000 \\
\hline Min. & -0.995 & 0.890 & -1.013 & 0.142 & -1.034 & -0.957 & -1.115 & 0.000 & 0.000 \\
\hline Std. & 0.184 & 0.104 & 0.161 & 0.041 & 0.131 & 0.096 & 0.121 & 0.476 & 0.436 \\
\hline
\end{tabular}

Panel B: Pearson Correlation

\begin{tabular}{|c|c|c|c|c|c|c|c|c|c|}
\hline & $E_{i t+1}$ & IndE $_{\text {it }}$ & FirmE $_{i t}$ & IndCF $_{i t}$ & FirmCF $_{\text {it }}$ & IndAcc $_{\text {it }}$ & FirmAcc $_{i t}$ & $\begin{array}{l}\text { Com- } \\
\text { pInd }\end{array}$ & $\mathrm{Neg}_{\text {it }}$ \\
\hline$E_{i t+1}$ & 1.000 & & & & & & & & \\
\hline IndE $_{\text {it }}$ & $0.143^{\mathrm{a}}$ & 1.000 & & & & & & & \\
\hline FirmE $_{i t}$ & 0.609 & 0.019 & 1.000 & & & & & & \\
\hline IndCF $_{\text {it }}$ & 0.226 & 0.371 & 0.000 & 1.000 & & & & & \\
\hline FirmCF $_{\text {it }}$ & 0.563 & 0.007 & 0.676 & 0.000 & 1.000 & & & & \\
\hline IndAcc $_{i t}$ & 0.059 & 0.920 & 0.020 & - & 0.008 & 1.000 & & & \\
\hline \multirow{2}{*}{$\begin{array}{l}\text { FirmAcc }_{\text {it }} \\
\text { Com- }^{-} \\
\text {pInd }_{\text {it }}\end{array}$} & 0.201 & 0.018 & 0.600 & 0.000 & -0.184 & 0.019 & 1.000 & & \\
\hline & -0.091 & 0.203 & -0.003 & 0.130 & -0.020 & -0.164 & 0.017 & 1.000 & \\
\hline $\mathrm{Neg}_{\text {it }}$ & -0.190 & 0.476 & -0.008 & 0.593 & -0.002 & -0.262 & -0.008 & 0.231 & 1.000 \\
\hline
\end{tabular}

aBold menunjukkan hubungan yang signifikan. 
demikian, mediannya masih menunjukkan angka yang positif, yaitu 0.014. Rata-rata variabel IndCF $F_{i t}$ dan FirmCF $F_{i t}$ masing-masing sebesar 0.060 dan 0.000 .

Sesuai dengan cara penghitungannya, nilai $I n d C F_{i t}$ dan FirmCF $F_{i t}$ akan berdampak pada nilai IndACc $_{\text {it }}$ dan FirmAcc it $_{\text {. Dalam }}$ Tabel 2 Panel A diketahui bahwa rata-rata IndAcc $_{\text {it }}$ dan FirmAcc it adalah -0.047 dan 0.001. Median dari variabel IndAcc ${ }_{i t}$ juga bernilai negatif, hal ini mengindikasikan bahwa komponen industry-wide atas akrual dalam periode penelitian ini mayoritas bernilai negatif. Rata-rata variabel CompInd $_{i t}$ adalah sebesar 0.653. Hal ini mengindikasikan bahwa $65.3 \%$ perusahaan berada pada industri yang level kompetisinya rendah. Sementara sisanya mengindikasikan perus- ahaan yang berada pada industri dengan level kompetisi yang tinggi.

Tabel 2 Panel B menunjukkan hubungan antar varibel yang digunakan dalam penelitian ini. Berdasarkan tabel tersebut diketahui bahwa di antara variabel $I n d E_{i t}$ dan FirmE $E_{i t}$ yang memiliki hubungan paling kuat dengan variabel Earnings $_{i t+1}$ adalah variabel FirmE $E_{i t .}$ Hal ini bertentangan dengan penelitian Hui et al., (2016) yang menunjukkan bahwa komponen industrywide atas laba lebih persisten dibandingkan dengan komponen firm-specific. Hal ini mungkin disebabkan oleh banyaknya industri dalam periode penelitian ini yang mengalami laba negatif. Kondisi tersebut juga tercermin pada variabel IndCF $F_{i t}$ Firm$C F_{i t}$, IndAcc $i t$, dan FirmAcc ${ }_{i t}$.

Tabel 3.

Level Kompetisi Industri terhadap Persistensi Industry-Wide dan Firm-Specific sebagai Komponen atas Laba

\begin{tabular}{|c|c|c|c|}
\hline & & Koefisien (t-statistik) (1) & Koefisien (t-statistik) (2) \\
\hline Intercept & $\alpha_{0}$ & $\begin{array}{c}-0.020 \\
(-8.410)^{* * *}\end{array}$ & $\begin{array}{c}0.015 \\
(3.260)^{*}\end{array}$ \\
\hline $\operatorname{IndE}_{\text {it }}$ & $\alpha_{1}$ & $\begin{array}{c}(-8.410)^{* * * *} \\
1.292\end{array}$ & $\begin{array}{c}0.015 \\
(3.260)^{*}\end{array}$ \\
\hline FirmE $_{\text {it }}$ & $\alpha_{2}$ & $\begin{array}{c}1.292 \\
(20.068)^{* * * *}\end{array}$ & $\begin{array}{c}0.739 \\
(7.316)^{* * * *}\end{array}$ \\
\hline $\mathrm{Neg}_{\text {it }}$ & $\alpha_{3}$ & $\begin{array}{l}-0.007 \\
(-2.468)\end{array}$ & $\begin{array}{c}0.004 \\
(1.326)\end{array}$ \\
\hline CompInd $_{\text {it }}$ & $\alpha_{4}$ & & $\begin{array}{c}-0.053 \\
(-8.760)^{* * * *}\end{array}$ \\
\hline $\operatorname{IndE}_{\mathrm{it}}{ }^{*} \mathrm{Neg}_{\mathrm{it}}$ & $\alpha_{5}$ & $\begin{array}{c}-1.318 \\
(-20.395)^{* * *}\end{array}$ & $\begin{array}{c}0.347 \\
(1.309)\end{array}$ \\
\hline $\operatorname{FirmE}_{\mathrm{it}} * \mathrm{Neg}_{\mathrm{it}}$ & $\alpha_{6}$ & $\begin{array}{c}-0.008 \\
(-0.941)\end{array}$ & $\begin{array}{c}0.152 \\
(6.230)^{* * * * *}\end{array}$ \\
\hline $\operatorname{IndE}_{\mathrm{it}} * \operatorname{CompInd}_{\mathrm{it}}$ & $\alpha_{7}$ & & $\begin{array}{c}0.969 \\
(7.491)^{* * * * *}\end{array}$ \\
\hline FirmE $_{i t}^{*}$ CompInd $_{i t}$ & $\alpha_{8}$ & & $\begin{array}{c}-0.070 \\
(-5.565)^{* \cdots * *}\end{array}$ \\
\hline $\operatorname{IndE}_{\mathrm{it}} * \mathrm{Neg}_{\mathrm{it}} * \mathrm{CompInd}_{\mathrm{it}}$ & $\alpha_{9}$ & & $\begin{array}{c}-2.081 \\
(-7.301)^{* * * * *}\end{array}$ \\
\hline FirmE $_{i t}{ }^{*} \mathrm{Neg}_{i t}{ }^{*}$ CompInd $_{i t}$ & $\alpha_{10}$ & & $\begin{array}{c}-0.167 \\
(-6.402)^{* * * *}\end{array}$ \\
\hline Adjusted $\mathrm{R}^{2}$ & & 0.645 & 0.647 \\
\hline F-test & & $(6.453)^{* * * *}$ & $(6.484)^{* * * *}$ \\
\hline $\begin{array}{l}\text { Wald-test: } \\
\alpha_{1}=\alpha_{2} \\
\alpha_{1}=\alpha_{1}+\alpha_{5} \\
\alpha_{2}=\alpha_{2}+\alpha_{6} \\
\alpha_{1}=\alpha_{1}+\alpha_{7}\end{array}$ & & $\begin{array}{c}\mathrm{p}<0.01^{* * *} \\
\mathrm{p}<0.01^{* * * *} \\
\mathrm{p}=0.64\end{array}$ & $\mathrm{p}<0.10 *\left(\mathrm{H}_{1}\right)$ \\
\hline
\end{tabular}

$*, * * * * *$ adalah signifikan pada level kepercayaan $90 \%, 95 \%, 99 \%$. 


\section{Pengujian Hipotesis}

Tabel 3 menyajikan hasil estimasi fixed effect atas pengaruh level kompetisi industri terhadap persistensi industry-wide dan firm -specific sebagai komponen atas laba. Pada Tabel 3 kolom (1) telah diuji persistensi industry-wide dan firm-specific sebagai komponen atas laba tanpa memasukkan level kompetisi industri. Sesuai dengan Hui et al., (2016), komponen industry-wide atas laba sebagaimana tersaji dalam Tabel 3 kolom (1), lebih persisten dibandingkan dengan komponen firm-specific atas laba. Berdasarkan tabel tersebut juga diketahui bahwa komponen industry-wide atas laba yang memiliki $I n d E_{i t}$ negatif kurang persisten dibandingkan dengan komponen industry-wide atas laba yang memiliki Ind $E_{i t}$ positif. Hal ini sesuai dengan hasil Wald-test yang menunjukkan bahwa $\mathrm{H}_{0}: \alpha_{1}=\alpha_{1}+\alpha_{5}$, signifikan pada level pada tingkat kepercayaan $99 \%$ dan nilai $\alpha_{1}>\alpha_{1}+\alpha_{5}$. Sementara itu, IndE $E_{i t}$ yang negatif tidak memberikan dampak yang berbeda terhadap persistensi firm-specific sebagai komponen atas laba.

Pada Tabel 3 kolom (2) dimasukkan variabel CompInd ${ }_{i t}$ untuk menguji $\mathrm{H}_{1}$, yaitu apakah komponen industry-wide atas laba pada low-competition industries lebih persisten dibandingkan komponen industrywide atas laba pada high-competition industries. Pada kolom tersebut diketahui bahwa secara bersama-sama, variabel independen signifikan memengaruhi variabel dependen. Hal ini dibuktikan dengan nilai signifikansi probabilitas (F-statistik) yang sebesar 0.000 (lebih kecil dari $\alpha=1 \%$ ). Dapat diambil suatu kesimpulan bahwa model pengujian persistensi laba secara keseluruhan menjelaskan dengan baik pengaruh level kompetisi industri terhadap persistensi industry-wide dan firm-specific sebagai komponen atas laba pada tingkat kepercayaan 99\%.

Nilai adjusted $\mathrm{R}^{2}$ pada model tersebut adalah sebesar 0.647 . Nilai adjusted $\mathrm{R}^{2}$ ini mengindikasikan bahwa variabilitas variabel dependen (Earnings ${ }_{i t+1}$ ) yang dapat dijelaskan oleh variabel independen adalah sebesar $64.7 \%$. Sisanya yang sebesar 35.3\% dijelaskan oleh variabel-variabel lain di luar model estimasi persistensi laba tersebut.

Secara individu, variabel $I n d E_{i t}$ mem- iliki koefisien yang positif, yaitu sebesar 0.739 . Koefisien variabel $I n d E_{i t}$ ini merepresentasikan persistensi industry-wide sebagai komponen atas laba perusahaan yang berada pada industri dengan level kompetisi yang tinggi dan laba industri yang positif. Dalam Tabel 3 kolom (2) juga diketahui bahwa variabel $I n d E_{i t}$ berpengaruh signifikan terhadap variabel Earnings ${ }_{i t+1}$ pada tingkat kepercayaan 99\%. Hal ini dapat dilihat dari nilai probabilitas (t-statistik) variabel $I n d E_{i t}$ yang lebih kecil dari $\alpha=1 \%$.

Variabel IndE ${ }_{i t}^{*}$ CompInd $_{i t}$ memiliki koefisien yang positif, yaitu sebesar 0.969. Koefisien variabel IndE $_{\text {it }}{ }^{*}$ CompInd $_{\text {it }}$ ini merepresentasikan perbedaan persistensi industry-wide sebagai komponen atas laba antara perusahaan yang berada pada industri dengan level kompetisi yang rendah dan tinggi dengan laba industri yang positif. Dalam Tabel 3 kolom (2) juga diketahui bahwa variabel IndE ${ }_{i t}^{*}$ CompInd $d_{i t}$ berpengaruh signifikan terhadap variabel Earnings $_{\text {ittl }}$ pada tingkat kepercayaan 99\%. Hal ini dapat dilihat dari nilai probabilitas (t-statistik) variabel $\operatorname{IndE}_{i t}{ }^{*}$ CompInd $_{i t}$ yang lebih kecil dari $\alpha=1 \%$.

Untuk lebih meyakinkan apakah komponen industry-wide atas laba pada lowcompetition industries $\left(\alpha_{1}+\alpha_{7}\right)$ lebih persisten dibandingkan komponen industry-wide atas laba pada high-competition industries $\left(\alpha_{1}\right)$, penulis melakukan Wald-test. Dalam pengujian ini, diketahui bahwa $\mathrm{HO}$ adalah $\alpha_{1}=\alpha_{1}+\alpha_{7}$. Hasil pengujian Wald-test menunjukkan bahwa nilai probabilitas (F-statistik) signifikan dan nilai $\alpha_{1}>\alpha_{1}+\alpha_{7}$. Hal ini berarti bahwa persistensi industry-wide sebagai komponen atas laba antara perusahaan yang berada pada industri dengan level kompetisi yang rendah dan tinggi dengan laba industri yang positif, berbeda dan signifikan. Dengan demikian, H1 dalam penelitian ini diterima.

Hasil penelitian ini mendukung penelitian sebelumnya bahwa industri yang kompetitif dapat memengaruhi perilaku manajerial dalam menyajikan laporan keuangan. Mueller (1977) menunjukkan bahwa semakin tinggi barriers-to-entry, semakin menurunkan level kompetisi. Hal ini terjadi lantaran terdapat batasan bagi perusahaan baru untuk masuk ke dalam industri terse- 
but. Penurunan kompetisi tersebut dapat menyebabkan market share menjadi relatif stabil. Perusahaan yang berada dalam industri tersebut dapat memiliki pertumbuhan laba yang berkelanjutan (sustainable). Berdasarkan Baginski et al., (1999), perusahaan yang berada pada industri dengan barriers-to-entry yang tinggi (product differentiation dan product innovation), memiliki market share yang relatif stabil sehingga cenderung memiliki laba yang lebih persisten. Menurut Hui et al., (2016), komponen laba juga lebih persisten pada industri yang stabil dibandingkan dengan pada industri yang terganggu dengan business shocks.

Tabel 4 (terlampir) menyajikan hasil estimasi pengaruh level kompetisi industri terhadap persistensi industry-wide dan firm -specific sebagai komponen atas arus kas dan akrual. Pada Tabel 4 kolom (1) telah diuji persistensi industry-wide dan firmspecific sebagai komponen atas arus kas dan akrual tanpa memasukkan level kompetisi industri. Berdasarkan tabel tersebut diketahui bahwa koefisien komponen industry-wide atas arus kas yang memiliki industry-wide atas laba positif, bernilai paling besar jika dibandingkan dengan komponen lainnya. Hal ini sesuai dengan hasil Wald-test yang signifikan pada level pada tingkat kepercayaan 99\% dan nilai $\alpha_{1}$ merupakan koefisien yang terbesar dibandingkan dengan $\alpha_{2} ; \alpha_{3} ; \alpha_{4} ; \alpha_{1}+\alpha_{7} ; \alpha_{2}+\alpha_{8} ; \alpha_{3}+\alpha_{9} ;$ dan $\alpha_{4}+\alpha_{10}$. Selain itu, koefisien komponen firmspecific atas akrual yang memiliki industrywide atas laba negatif, bernilai paling kecil jika dibandingkan dengan komponen lainnya. Hal ini sesuai dengan hasil Waldtest yang signifikan pada level pada tingkat kepercayaan $99 \%$ dan nilai $\alpha_{4}+\alpha_{10}$ merupakan koefisien yang terkecil dibandingkan dengan $\alpha_{1} ; \alpha_{2} ; \alpha_{3} ; \alpha_{4} ; \alpha_{1}+\alpha_{7} ; \alpha_{2}+\alpha_{8} ;$ dan $\alpha_{3}+\alpha_{9}$. Hasil ini sesuai dengan studi Hui et al., (2016), Sloan (1996), dan Dechow \& Dichev (2002).

Pada Tabel 4 kolom (2) dimasukkan variabel CompInd $d_{i t}$ untuk menguji $\mathrm{H}_{2 \mathrm{a}}$ dan $\mathrm{H}_{2 \mathrm{~b}}$. Pada kolom tersebut diketahui bahwa secara bersama-sama, variabel independen signifikan memengaruhi variabel dependen. Hal ini dibuktikan dengan nilai signifikansi probabilitas (F-statistik) yang sebesar 0.000 (lebih kecil dari $\alpha=1 \%$ ). Dapat diambil suatu kesimpulan bahwa model pengujian persistensi komponen arus kas dan akrual secara keseluruhan menjelaskan dengan baik pengaruh level kompetisi industri terhadap persistensi industry-wide dan firm-specific sebagai komponen atas laba pada tingkat kepercayaan $99 \%$.

Nilai adjusted $\mathrm{R}^{2}$ pada model tersebut adalah sebesar 0.652. Nilai adjusted $\mathrm{R}^{2}$ ini mengindikasikan bahwa variabilitas variabel dependen (Earnings ${ }_{i t+1}$ ) yang dapat dijelaskan oleh variabel independen adalah sebesar $65.2 \%$. Sisanya yang sebesar 34.8\% dijelaskan oleh variabel-variabel lain di luar model estimasi persistensi laba tersebut.

Untuk menguji H2a, apakah komponen industry-wide atas arus kas pada lowcompetition industries yang memiliki industry-wide atas laba positif merupakan komponen yang paling persisten jika dibandingkan dengan komponen lainnya, penelitian ini menggunakan Wald-test. Penelitian ini menduga bahwa koefisien $\alpha 1+\alpha 11$ akan bernilai paling besar dibandingkan dengan $\alpha 1 ; \alpha 2 ; \alpha 3 ; \alpha 4 ; \alpha 1+\alpha 7$; $\alpha 2+\alpha 8 ; \alpha 3+\alpha 9 ; \alpha 4+\alpha 10 ; \alpha 2+\alpha 12 ; \alpha 3+\alpha 13 ; \alpha 4+\alpha 14$; $\alpha 1+\alpha 7+\alpha 11+\alpha 15 ; \quad \alpha 2+\alpha 8+\alpha 12+\alpha 16 ; \quad \alpha 3+\alpha 9+\alpha 13+$ $\alpha 17$; dan $\alpha 4+\alpha 10+\alpha 14+\alpha 18$. Hasil pengujian Wald Test menunjukkan bahwa nilai probabilitas (F-statistik) signifikan dan nilai $\alpha 1+\alpha 11$ memiliki koefisien yang paling besar jika dibandingkan dengan koefisien pada komponen lainnya. Dengan demikian, H2a dalam penelitian ini diterima.

Untuk menguji H2b, apakah komponen firm-specific atas akrual pada highcompetition industries yang memiliki industry-wide atas laba negatif merupakan komponen yang paling kurang persisten jika dibandingkan dengan komponen lainnya, penelitian ini juga menggunakan Wald-test. Penelitian ini menduga bahwa koefisien $\alpha 4+\alpha 10$ akan bernilai paling kecil dibandingkan dengan $\alpha 1 ; \alpha 2 ; \alpha 3 ; \alpha 4 ; \alpha 1+\alpha 7 ; \alpha 2+\alpha 8$; $\alpha 3+\alpha 9 ; \quad \alpha 1+\alpha 11 ; \quad \alpha 2+\alpha 12 ; \quad \alpha 3+\alpha 13 ; \quad \alpha 4+\alpha 14 ;$ $\alpha 1+\alpha 7+\alpha 11+\alpha 15 ; \quad \alpha 2+\alpha 8+\alpha 12+\alpha 16 ; \quad \alpha 3+\alpha 9+\alpha 13+$ $\alpha 17$; dan $\alpha 4+\alpha 10+\alpha 14+\alpha 18$. Hasil pengujian Wald-test menunjukkan bahwa nilai probabilitas (F-statistik) signifikan dan nilai $\alpha 4+\alpha 10$ memiliki koefisien yang paling kecil jika dibandingkan dengan koefisien pada 
komponen lainnya. Dengan demikian, H2b dalam penelitian ini diterima.

Hasil penelitian ini mendukung studi Hui et al., (2016), Sloan (1996), dan Dechow \& Dichev (2002). Sloan (1996) membuktikan bahwa komponen akrual dari laba kurang persisten terhadap laba di masa depan dibandingkan dengan komponen arus kas dari laba. Hui et al., (2016) menunjukkan bahwa industry-wide atas arus kas merupakan komponen laba yang paling persisten sementara firm-specific atas akrual merupakan komponen laba yang paling kurang persisten. Dechow \& Dichev (2002) menyatakan bahwa perusahaan yang melaporkan laba negatif akan memiliki kualitas laba yang lebih rendah dibandingkan dengan perusahaan yang melaporkan laba positif.

\section{Analisis Pengujian Tambahan}

Sebagaimana diulas sebelumnya, penelitian ini menggunakan pengukuran alternatif atas kompetisi industri untuk memastikan apakah komponen industry-wide atas laba pada low-competition industries lebih persisten dibandingkan komponen industrywide atas laba pada high-competition industries. Dalam hal ini, penelitian ini menggunakan pendekatan size inequality yang lain, yaitu $R M D_{t}$. Hasil pengujian sebagaimana disajikan dalam Tabel 3 dan Tabel 4 robust dengan hasil yang disajikan dalam Tabel 5 (terlampir).

\section{SIMPULAN}

Penelitian ini bertujuan untuk menginvestigasi apakah persistensi laba, arus kas, dan akrual dipengaruhi oleh level kompetisi di suatu industri. Penelitian ini dilakukan untuk mengisi gap penelitian Hui et al., (2016). Penelitian ini berkontribusi dalam menambah literatur terkait persistensi laba. Penelitian ini menunjukkan bahwa terdapat perbedaan persistensi komponen industry-wide dan firm-specific yang terkandung dalam laba, arus kas, dan akrual antara high-competition industries dan lowcompetition industries. Dalam penelitian Hui et al., (2016) tidak mengakomodir dampak level kompetisi industri terhadap persistensi laba, hanya menguji dampak industry homogeneity dan business shocks.

Sesuai dengan pembahasan hasil, dapat diambil kesimpulan bahwa komponen industry-wide atas laba pada lowcompetition industries lebih persisten dibandingkan komponen industry-wide atas laba pada high-competition industries. Hal ini mengindikasikan bahwa kualitas laba perusahaan yang berada pada lowcompetition industries lebih tinggi dibandingkan dengan perusahaan yang berada pada high-competition industries. Selaras dengan hal tersebut, penelitian ini juga berhasil menemukan bahwa komponen industry-wide atas arus kas pada lowcompetition industries yang memiliki industry-wide atas laba positif merupakan komponen yang paling persisten jika dibandingkan dengan komponen lainnya. Selain itu, komponen firm-specific atas akrual pada high-competition industries yang memiliki industry-wide atas laba negatif merupakan komponen yang paling kurang persisten jika dibandingkan dengan komponen lainnya. Hasil penelitian ini mendukung penelitian sebelumnya (Hui et al., 2016; Sloan, 1996; dan Dechow \& Dichev, 2002).

Penelitian ini diharapkan dapat memberikan manfaat bagi investor. Melalui pengujian yang dilakukan, investor dapat mengetahui bahwa perusahaan dengan level kompetisi industri yang berbeda, memiliki persistensi yang berbeda pula. Dengan demikian, ketika melakukan penilaian terhadap suatu perusahaan, investor sebaiknya tidak hanya terfokus pada laba yang dilaporkan perusahaan saja, melainkan juga mempertimbangkan faktor-faktor lain, seperti level kompetisi industri perusahaan.

\section{KETERBATASAN DAN SARAN}

Keterbatasan dalam studi ini adalah periode penelitian yang digunakan cukup singkat, yaitu hanya 3 tahun. Untuk penelitian selanjutnya diharapkan dapat menambah periode penelitian untuk mendapatkan hasil yang lebih baik. Selain itu, penelitian selanjutnya diharapkan menggunakan proksi kompetisi industri dengan pendekatan lainnya, seperti pendekatan market consentration sehingga hasil penelitian menjadi lebih robust. Sementara itu, 
penelitian ini hanya menggunakan pendekatan size inequality.

\section{DAFTAR PUSTAKA}

Arieftiara, D., Utama, S., \& Wardhani, R. (2017). Environmental uncertainty as a contingent factor of business strategy decisions: Introducing an alternative measure of uncertainty. Australasian Accounting, Business and Finance Journal, 11(4): 116-130.

Arieftiara, D., Utama, S., Wardhani, R., Rahayu, N. (2019). Contingent fit between business strategies and environmental uncertainty: The impact on corporate tax avoidance in Indonesia. Meditari Accountancy Research, 28(1): 139-167.

Atashband, A., Moienadin, M., \& Tabatabaenasab, Z. (2014). Examining the earnings persistence and its components in explaining the future profitability. Interdisciplinary Journal of Contemporary Research in Business, 5(10).

Baginski, S.P., Lorek, K.S., Willinger, G.L. \& Branson, B.C.. (1999). The relationship between economic characteristics and alternative annual earnings. The Accounting Review, 74(1), 105120.

Dechow, P.M., \& Dichev, I.D. (2002). The quality of accruals and earnings: The role of accrual estimation errors. The Accounting Review, 77, 35-59.

Dechow, P.M., Ge, W., \& Schrand, C. (2010). Understanding earnings quality: A review of the proxies, their determinants, and their consequences. Journal of Accounting and Economics, 50 (2-3), 344-401.

Dichev, I., Graham, J., Harvey, C., \& Rajgopal, S. (2013). Earnings quality: Evidence from the field. Journal of Accounting and Economics, 56: 1-33.

Du, J. and Chen, M. (2010). Market competition measurements and firms' R\&D responses to market competition pressure. Journal of Economic Literature, 1-25.

Ecker, F., Francis, J., Olsson, P., \& Schipper, K. (2013). Estimation sample selection for discretionary accruals models. Journal of Accounting and Economics, 56: 190-211.

Fatma, N., \& Hidayat, W. (2019). Earnings persistence, earnings power, and equity valuation in consumer goods firms. Asian Journal of Accounting Research.

Green, J., Hand, J., \& Soliman, M. (2011).
Going, going, gone? The demise of the accruals anomaly. Management Science, 57: 797-816.

Guay, W., Taylor, D., \& Xiao, J. (2014). Adaptor perish: Evidence of CEO adaptability to industry shocks. Workingpaper.

Healy, P., Serafeim, G., Srinivasan, S., \& Yu, G. (2014). Market competition, earnings management, and persistence in accounting profitability around the world. Review of Accounting Studies, 19: 1281-1308.

Hui, K.W., Nelson, K.K., \& Yeung, P.E. (2016). On the persistence and pricing of industry-wide and firm-specific earnings, cash flows, and accruals. Jounal of Accounting and Economics, 61, 185-202.

Li, X. (2010). The impact of product market competition on the quantity and quality of voluntary disclosures. Review of Accounting Studies, 15(3), 663 $-711$.

Marlianti, P.D., \& Devie. (2017). Pengaruh market competition intensities terhadap earning persistence melalui earning management sebagai variabel intervening di Indonesia pada perusahaan yang terdaftar di LQ 45 dalam Bursa Efek Indonesia (BEI). Business Accounting Review, 5(2).

Meini, Z., \& Siregar, S.V.N.P. (2014). The effect of accrual earnings management and real earnings management on earnings persistence and cost of equity. Journal of Economics, Business, and Accountancy Ventura, 17(2): 269280.

Meini, Z., Safuan, S., Dewo, S.A., \& Diyanti, V. (2018). Business cycles and earnings persistence: Evidence from the ASEAN-5 countries. International Journal of Economics and Management, 12(S1): 105-118.

Merrysa, L.W., \& Rachmawati, N.A. (2017). Manajemen laba dan perencanaan pajak sebagai sumber large positive book-tax differences terhadap persistensi laba. Jurnal Akuntansi Bisnis, 10 (2), 123-134.

Mueller, D.C. (1977). The persistence of profits above the norm. Economica, 44 (November): 380-391.

Rachmawati, N.A., \& Martani, D. (2014). Pengaruh large positive abnormal book-tax differences terhadap persistensi laba. Jurnal Akuntansi dan Keuangan Indonesia, 11(2), 120-137.

Rachmawati, N.A. (2016). Book-tax conformity dan kualitas laba. Jurnal Riset dan Aplikasi: Akuntansi dan Mana- 
Persistensi Laba antar Level Kompetisi Industri: Studi pada Perusahaan Amerika Serikat (Rachmawati, Utama, dan Siregar)

jemen, 1(3), 192-201.

Sloan, R.G. (1996). Do stock prices fully reflect information in accruals and cash flows about future earnings? The Accounting Review, 71, 289-315.
Wahlen, J., Baginski, S., \& Bradshaw, M. (2015). Financial reporting, financial statement analysis and valuation, 8th ed. South-Western Cengage Learning. 


\section{LAMPIRAN}

Tabel 4.

Level Kompetisi Industri terhadap Persistensi Industry-Wide dan Firm-Specific sebagai Komponen atas Arus Kas dan Akrual

\begin{tabular}{|c|c|c|c|}
\hline & & $\begin{array}{c}\text { Koefisien (t-statistik) } \\
(1)\end{array}$ & $\begin{array}{c}\text { Koefisien (t-statistik) } \\
(2) \\
\end{array}$ \\
\hline \multirow[t]{2}{*}{ Intercept } & $\alpha_{0}$ & -0.038 & -0.011 \\
\hline & & $(-8.468)^{* * *}$ & $(-1.452)$ \\
\hline \multirow{2}{*}{ IndCF $_{\text {it }}$} & $\alpha_{1}$ & 1.545 & 1.079 \\
\hline & & $(9.987)^{* * * *}$ & $(9.009)^{* * *}$ \\
\hline \multirow{2}{*}{ FirmCF $_{\text {it }}$} & $\alpha_{2}$ & 0.068 & 0.093 \\
\hline & & $(7.927)^{* * * *}$ & $(6.337)^{* * *}$ \\
\hline \multirow{2}{*}{ IndAcc $_{\text {it }}$} & $\alpha_{3}$ & 1.227 & 0.555 \\
\hline & & $(17.680)^{* * * *}$ & $(5.238)^{* * *}$ \\
\hline \multirow{2}{*}{ FirmAcc $_{\text {it }}$} & $\alpha_{4}$ & -0.067 & 0.555 \\
\hline & & $(-10.711)^{* * * *}$ & $(5.238)^{* * *}$ \\
\hline \multirow{2}{*}{$\mathrm{Neg}_{\text {it }}$} & $\alpha_{5}$ & -0.007 & -0.003 \\
\hline & & $(-1.394)$ & $(-0.535)$ \\
\hline \multirow[t]{2}{*}{ CompInd $_{\text {it }}$} & $\alpha_{6}$ & & -0.036 \\
\hline & & & $(-3.530)^{* * *}$ \\
\hline \multirow{2}{*}{$\operatorname{IndCF}_{\text {it }} * \mathrm{Neg}_{\mathrm{it}}$} & $\alpha_{7}$ & -1.154 & 0.125 \\
\hline & & $(-11.247)^{* * * *}$ & $(0.381)$ \\
\hline \multirow{2}{*}{ FirmCF $_{\text {it }} * \mathrm{Neg}_{\mathrm{it}}$} & $\alpha_{8}$ & 0.018 & 0.142 \\
\hline & & (1.539) & $(4.940)^{* * *}$ \\
\hline \multirow{2}{*}{$\operatorname{IndACc}_{i t} * \mathrm{Neg}_{\mathrm{it}}$} & $\alpha_{9}$ & -1.245 & -0.236 \\
\hline & & $(-17.898)^{* * * *}$ & $(-0.778)$ \\
\hline \multirow{2}{*}{ FirmAcc $_{\mathrm{it}} * \mathrm{Neg}_{\mathrm{it}}$} & $\alpha_{10}$ & -0.059 & 0.109 \\
\hline & & $(-5.902)^{* * * *}$ & $(3.573)^{* * *}$ \\
\hline \multirow{2}{*}{ IndCF $_{\text {it }}{ }^{*}$ CompInd $_{\text {it }}$} & $\alpha_{11}$ & & -0.795 \\
\hline & & & $(5.097)^{* * * *}$ \\
\hline \multirow{2}{*}{ FirmCF $_{\text {it }} *$ CompInd $_{\text {it }}$} & $\alpha_{12}$ & & -0.031 \\
\hline & & & $(-1.870)$ \\
\hline \multirow{2}{*}{ IndAcc $_{\text {it }}{ }^{*}$ CompInd $_{\text {it }}$} & $\alpha_{13}$ & & 1.155 \\
\hline & & & $(8.415)^{* * *}$ \\
\hline \multirow[t]{2}{*}{ FirmAcc $_{\text {it }}{ }^{*}$ CompInd $_{i t}$} & $\alpha_{14}$ & & -0.075 \\
\hline & & & $(-5.431)^{* * * *}$ \\
\hline \multirow{2}{*}{$\operatorname{IndCF}_{\mathrm{it}}{ }^{*} \mathrm{Neg}_{\mathrm{it}}{ }^{*} \mathrm{CompInd}_{\mathrm{it}}$} & $\alpha_{15}$ & & -1.647 \\
\hline & & & $(-4.454)^{* * *}$ \\
\hline \multirow[t]{2}{*}{ FirmCF $_{\text {it }}{ }^{*} \mathrm{Neg}_{\mathrm{it}}{ }^{*} \mathrm{CompInd}_{\mathrm{it}}$} & $\alpha_{16}$ & & -0.137 \\
\hline & & & $(-4.398)^{* * *}$ \\
\hline \multirow{2}{*}{$\operatorname{IndACc}_{\mathrm{it}} * \mathrm{Neg}_{\mathrm{it}} * \mathrm{CompInd}_{\mathrm{it}}$} & $\alpha_{17}$ & & -1.493 \\
\hline & & & $(-4.758) * * *$ \\
\hline \multirow{2}{*}{ FirmAcc $_{i t}{ }^{*} \operatorname{Neg}_{i t} *$ CompInd $_{i t}$} & $\alpha_{18}$ & & -0.170 \\
\hline & & & $(-5.260)^{* * * *}$ \\
\hline \multicolumn{2}{|l|}{ Adjusted $\mathrm{R}^{2}$} & 0.651 & 0.652 \\
\hline \multicolumn{2}{|l|}{ F-test } & $(6.583)^{* * * *}$ & $(6.607)^{* * *}$ \\
\hline Wald-test: & & & \\
\hline$\alpha_{1}=\alpha_{2}=\alpha_{3}=\alpha_{4}=\alpha_{1}+\alpha_{7}=\alpha_{2}+\alpha_{8}=\alpha_{3}$ & & & \\
\hline & & $\mathrm{p}<0.01 * * *$ & \\
\hline$\alpha_{4}+\alpha_{10}=\alpha_{1}=\alpha_{2}=\alpha_{3}=\alpha_{4}=\alpha_{1}+\alpha_{7}=\alpha$ & & & \\
\hline & & $\mathrm{p}<0.01 \% * *$ & \\
\hline$\alpha_{1}+\alpha_{11}=\alpha_{1}=\alpha_{2}=\alpha_{3}=\alpha_{4}=\alpha_{1}+\alpha_{7}=\alpha$ & $-\alpha_{9}=\alpha_{4}+\alpha_{1}$ & & \\
\hline${ }_{0}=\alpha_{2}+\alpha_{12}=\alpha_{3}+\alpha_{13}=\alpha_{4}+\alpha_{14}=\alpha_{1}+\alpha$ & ${ }_{5}=\alpha_{2}+\alpha_{8}+$ & & \\
\hline$\alpha_{12}+\alpha_{16}=\alpha_{3}+\alpha_{9}+\alpha_{13}+\alpha_{17}=\alpha_{4}+\alpha_{10}$ & & & $\mathrm{p}<0.01 * * *\left(\mathrm{H}_{2 \mathrm{a}}\right)$ \\
\hline$\alpha_{4}+\alpha_{10}=\alpha_{1}=\alpha_{2}=\alpha_{3}=\alpha_{4}=\alpha_{1}+\alpha_{7}=\alpha$ & $-\alpha_{9}=\alpha_{1}+\alpha_{1}$ & & \\
\hline${ }_{1}=\alpha_{2}+\alpha_{12}=\alpha_{3}+\alpha_{13}=\alpha_{4}+\alpha_{14}=\alpha_{1}+\alpha$ & ${ }_{5}=\alpha_{2}+\alpha_{8}+$ & & \\
\hline$\alpha_{12}+\alpha_{16}=\alpha_{3}+\alpha_{9}+\alpha_{13}+\alpha_{17}=\alpha_{4}+\alpha_{10}$ & & & $\mathrm{p}<0.01^{* * *}\left(\mathrm{H}_{2 \mathrm{~h}}\right)$ \\
\hline
\end{tabular}


Tabel 4. (Lanjutan)

Level Kompetisi Industri terhadap Persistensi Industry-Wide dan Firm-Specific sebagai Komponen atas Arus Kas dan Akrual

\begin{tabular}{|c|c|c|}
\hline & $\begin{array}{l}\text { Koefisien (t-statistik) } \\
\text { (1) }\end{array}$ & $\begin{array}{c}\text { Koefisien (t-statistik) } \\
(2) \\
\end{array}$ \\
\hline Adjusted $\mathrm{R}^{2}$ & 0.651 & 0.652 \\
\hline F-test & $(6.583) * * *$ & $(6.607)^{* * * *}$ \\
\hline \multicolumn{3}{|l|}{ Wald-test: } \\
\hline$\alpha_{1}=\alpha_{2}=\alpha_{3}=\alpha_{4}=\alpha_{1}+\alpha_{7}=\alpha_{2}+\alpha_{8}=\alpha_{3}+\alpha_{9}=\alpha_{4}+\alpha_{10}$ & $\mathrm{p}<0.01^{* * * *}$ & \\
\hline$\alpha_{4}+\alpha_{10}=\alpha_{1}=\alpha_{2}=\alpha_{3}=\alpha_{4}=\alpha_{1}+\alpha_{7}=\alpha_{2}+\alpha_{8}=\alpha_{3}+\alpha_{9}$ & $\mathrm{p}<0.01 * * *$ & \\
\hline \multicolumn{3}{|l|}{$\alpha_{1}+\alpha_{11}=\alpha_{1}=\alpha_{2}=\alpha_{3}=\alpha_{4}=\alpha_{1}+\alpha_{7}=\alpha_{2}+\alpha_{8}=\alpha_{3}+\alpha_{9}=\alpha_{4}$} \\
\hline \multicolumn{3}{|l|}{$\begin{array}{l}+\alpha_{10}-\alpha_{2}+\alpha_{12}-\alpha_{3}+\alpha_{13}-\alpha_{4}+\alpha_{14}-\alpha_{1}+\alpha_{7}+\alpha_{11}+\alpha_{15}^{-} \\
\alpha_{2}+\alpha_{8}+\alpha_{12}+\alpha_{16}=\alpha_{3}+\alpha_{9}+\alpha_{13}+\alpha_{17}=\alpha_{4}+\alpha_{10}+\alpha_{14}+\alpha\end{array}$} \\
\hline \multicolumn{3}{|l|}{18} \\
\hline \multicolumn{3}{|l|}{$\alpha_{4}+\alpha_{10}=\alpha_{1}=\alpha_{2}=\alpha_{3}=\alpha_{4}=\alpha_{1}+\alpha_{7}=\alpha_{2}+\alpha_{8}=\alpha_{3}+\alpha_{9}=\alpha_{1}$} \\
\hline \multicolumn{3}{|l|}{$\begin{array}{l}+\alpha_{11}=\alpha_{2}+\alpha_{12}=\alpha_{3}+\alpha_{13}=\alpha_{4}+\alpha_{14}=\alpha_{1}+\alpha_{7}+\alpha_{11}+\alpha_{15}= \\
\alpha_{2}+\alpha_{8}+\alpha_{12}+\alpha_{16}=\alpha_{3}+\alpha_{9}+\alpha_{13}+\alpha_{17}=\alpha_{4}+\alpha_{10}+\alpha_{14}+\alpha\end{array}$} \\
\hline \multicolumn{3}{|l|}{18} \\
\hline \multicolumn{3}{|c|}{ 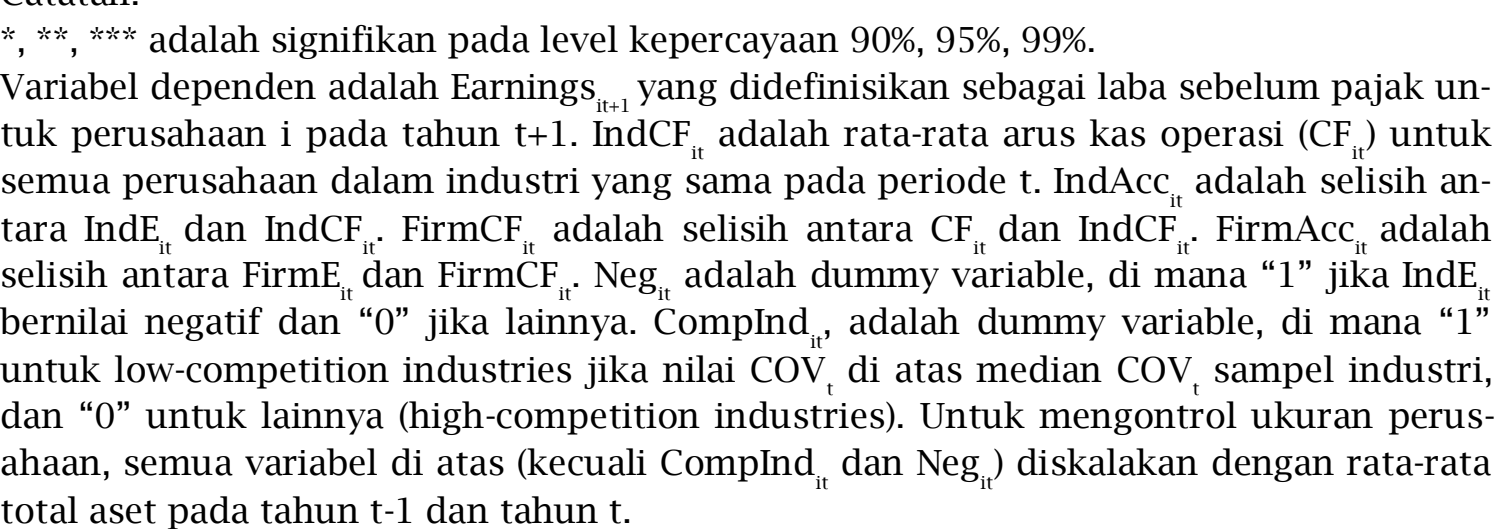 } \\
\hline
\end{tabular}


Tabel 5.

Robustness Check: Level Kompetisi Industri terhadap Persistensi Industry-Wide dan Firm-Specific sebagai Komponen atas Laba, Arus Kas, dan Akrual

\begin{tabular}{|c|c|c|}
\hline & Koefisien (1) & Koefisien (2) \\
\hline Intercept & -0.002 & $-0.025^{* *}$ \\
\hline $\operatorname{IndE}_{\mathrm{it}}$ & $\begin{array}{l}1.049 * * * * \\
0.684 * * *\end{array}$ & \\
\hline FirmE $_{\text {it }}$ & & \\
\hline IndCF $_{\text {it }}$ & & $1.363 * * *$ \\
\hline FirmCF $_{\text {it }}$ & & $0.132 * * * *$ \\
\hline Ind $A c c_{i t}$ & & $1.047^{* * * *}$ \\
\hline FirmAcc $_{\text {it }}$ & $-0.025^{* * * *}$ & 0.008 \\
\hline $\mathrm{Neg}_{\text {it }}$ & $-0.010 * * *$ & -0.016 \\
\hline $\mathrm{RMD}_{\mathrm{it}}$ & $-0.679 * *$ & -0.009 \\
\hline $\operatorname{IndE}_{\mathrm{it}}{ }^{*} \mathrm{Neg}_{\mathrm{it}}$ & -0.019 & \\
\hline $\operatorname{FirmE}_{\mathrm{it}}{ }^{*} \mathrm{Neg}_{\mathrm{it}}$ & & \\
\hline $\operatorname{IndCF}_{\mathrm{it}}{ }^{*} \mathrm{Neg}_{\mathrm{it}}$ & & $-0.839 *$ \\
\hline FirmCF $_{\text {it }} * \mathrm{Neg}_{\mathrm{it}}$ & & 0.054 \\
\hline $\operatorname{IndAcc}_{\mathrm{it}}{ }^{*} \mathrm{Neg}_{\mathrm{it}}$ & & -0.514 \\
\hline FirmAcc $_{\text {it }}{ }^{*} \mathrm{Neg}_{\text {it }}$ & $0.164 * *$ & $-0.197 * \cdots *$ \\
\hline $\operatorname{IndE}_{\mathrm{it}}{ }^{*} \mathrm{RMD}_{\mathrm{it}}$ & $-0.162^{* * * *}$ & \\
\hline FirmE $_{\text {it }} * \mathrm{RMD}_{\mathrm{it}}$ & & \\
\hline $\operatorname{IndCF}_{\mathrm{it}} * \mathrm{RMD}_{\mathrm{it}}$ & & 0.150 \\
\hline FirmCF $_{\text {it }} * \mathrm{RMD}_{\mathrm{it}}$ & & $-0.093 * * *$ \\
\hline $\operatorname{IndACc}_{\mathrm{it}}{ }^{*} \mathrm{RMD}_{\mathrm{it}}$ & & 0.226 \\
\hline $\operatorname{FirmAcc}_{\mathrm{it}}{ }^{*} \mathrm{RMD}_{\mathrm{it}}$ & $-0.518^{*}$ & $-0.107^{* * * *}$ \\
\hline $\operatorname{IndE}_{\mathrm{it}}{ }^{*} \mathrm{Neg}_{\mathrm{it}}{ }^{*} \mathrm{RMD}_{\mathrm{it}}$ & $0.145 * * *$ & \\
\hline $\operatorname{FirmE}_{\mathrm{it}} * \mathrm{Neg}_{\mathrm{it}} * \mathrm{RMD}_{\mathrm{it}}$ & & \\
\hline $\operatorname{IndCF}_{\text {it }} * \mathrm{Neg}_{\mathrm{it}} * \mathrm{RMD}_{\mathrm{it}}$ & & 0.042 \\
\hline FirmCF $_{\text {it }}{ }^{*} \mathrm{Neg}_{\text {it }} * \mathrm{RMD}_{\mathrm{it}}$ & & -0.014 \\
\hline $\operatorname{IndAcc}_{\mathrm{it}}{ }^{*} \mathrm{Neg}_{\mathrm{it}} * \mathrm{RMD}_{\mathrm{it}}$ & & -0.773 \\
\hline FirmAcc $_{i t} * \operatorname{Neg}_{\mathrm{it}} * \mathrm{RMD}_{\mathrm{it}}$ & & $0.171^{* *}$ \\
\hline Adjusted R² & 0.646 & 0.652 \\
\hline F-test & $(6.647)^{* * *}$ & $(6.599) * * *$ \\
\hline Wald-test: & & \\
\hline$\alpha_{1}=\alpha_{1}+\alpha_{7}$ & $\mathrm{p}<0.01 * * *\left(\mathrm{H}_{1}\right)$ & \\
\hline $\begin{array}{l}\alpha_{1}+\alpha_{11}=\alpha_{1}=\alpha_{2}=\alpha_{3}=\alpha_{4}=\alpha_{1}+\alpha_{7}=\alpha_{2}+\alpha_{8}=\alpha_{3}+\alpha_{9}=\alpha_{4}+\alpha_{10}=\alpha_{2}+\alpha_{12} \\
=\alpha_{3}+\alpha_{13}=\alpha_{4}+\alpha_{14}=\alpha_{1}+\alpha_{7}+\alpha_{11}+\alpha_{15}=\alpha_{2}+\alpha_{8}+\alpha_{12}+\alpha_{16}=\alpha_{3}+\alpha_{9}+\alpha_{1} \\
{ }_{3}+\alpha_{17}=\alpha_{4}+\alpha_{10}+\alpha_{14}+\alpha_{18} \\
\alpha_{4}+\alpha_{10}=\alpha_{1}=\alpha_{2}=\alpha_{3}=\alpha_{4}=\alpha_{1}+\alpha_{7}=\alpha_{2}+\alpha_{2}=\alpha_{2}+\alpha_{0}=\alpha_{1}+\alpha_{11}=\alpha_{0}+\alpha_{1}\end{array}$ & & $\mathrm{p}<0.01 * * * *\left(\mathrm{H}_{2 \mathrm{a}}\right)$ \\
\hline $\begin{array}{l}\alpha_{4}+\alpha_{10}=\alpha_{1}=\alpha_{2}=\alpha_{3}=\alpha_{4}=\alpha_{1}+\alpha_{7}=\alpha_{2}+\alpha_{8}=\alpha_{3}+\alpha_{9}=\alpha_{1}+\alpha_{11}=\alpha_{2}+\alpha_{1} \\
2=\alpha_{3}+\alpha_{13}=\alpha_{4}+\alpha_{14}=\alpha_{1}+\alpha_{7}+\alpha_{11}+\alpha_{15}=\alpha_{2}+\alpha_{8}+\alpha_{12}+\alpha_{16}=\alpha_{3}+\alpha_{9}+\alpha \\
13+\alpha_{17}=\alpha_{4}+\alpha_{10}+\alpha_{14}+\alpha_{18}\end{array}$ & & $\mathrm{p}<0.01 * * * *\left(\mathrm{H}_{2 \mathrm{~b}}\right)$ \\
\hline
\end{tabular}

